\title{
Teaching Methods In International Law
}

\author{
Carmelo Cattafi, Tecnológico de Monterrey, Mexico
}

\begin{abstract}
This research presents the effect of innovation in the educational methodology applied to the teaching of topics in different areas, especially in public international law, trying to demonstrate how learning can be stimulated through artistic awareness. When comparing the different generations of students, we wonder if it is possible for teachers to follow the step of digital natives. In order to fill this generation gap, Tecnologico de Monterrey proposed to support projects of experimentation in educational innovation in various topics related to improving the teaching-learning process. Based on this premise, a group of teachers generate a model of educational innovation training, to facilitate learning for students through the development of creativity in how, when and where to generate learning, integrating challenging and interactive experiences through activities within the teaching practice. The use of traditional methods has led to the overwhelm of teachers, fatigue and pressure, therefore, the contribution of this project is aimed at the teacher to internalize his innovative and creative work, and see himself as a leader transformative in its teaching practice, establishing new teaching-learning spaces. Implementing learning activities through the imagination and measuring the impact on the student of the use of creative activities allows us to improve what we currently do. For this, an interdisciplinary workshop was created (thought and word, mind and body, music, visual arts) where the teacher, through practical and experiential activities, stimulates his imagination, recognizes his talents in creative and innovative thinking and develops resources which then leads to their teaching practice, by designing challenging learning experiences that inspire the student to creatively solve tasks and projects. In order to carry out the objective, we gathered eight professors from different areas (law, international relations, political science, languages, architecture, art, cultural diffusion) convinced that creativity improves the teacher's performance who rethinks its activities to allow learn more dynamically. It was sought to improve the performance of students who appreciated the approach to the subjects through didactic methods that the teacher had modified according to the passions observed outside the classroom.
\end{abstract}

Keywords: Public International Law; Educational Innovation; Educational Methodology; Teaching and Learning; Education Research

\section{INTRODUCTION}

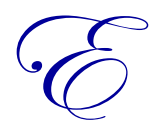

ducational innovation with human sense is important to explore. This research presents the effect of innovation in the educational methodology applied to the delivery of subjects in different areas, with particular attention on the course of public international law, trying to demonstrate how learning can be stimulated through artistic awareness and allows students to have a different approach on the subjects and get closer to the basics of the discipline in a more encouraging way.

When comparing the different generations of students we ask ourselves if it is possible for teachers to follow the step of the digital natives. To fill this generational gap, at the Tecnológico de Monterrey we proposed to support experimentation projects in educational innovation on various topics related to improving the teaching-learning process. Based on this premise, a group of teachers generated a model of training in educational innovation, to facilitate learning to students through the development of creativity in how, when and where to create learning, integrating challenging and interactive experiences through activities within the teaching practice.

The use of traditional methods has led to the overwhelm of teachers, fatigue and pressure, so, the contribution of this project is aimed at the teacher to internalize their innovative and creative work, and see himself as a transforming leader in his teaching practice, establishing new teaching-learning spaces. Implementing learning activities through imagination and measuring the impact on the student of the use of creative activities allows us to improve what we do now. 
The project "Enseña con Pasión, Aprende con Imaginación” (Teach with Passion, Learn with Imagination), aims that the teacher achieves a personal change through self-knowledge and artistic awareness to strengthen their creative thinking and impact on their academic work. The learning process is associated with the determining role of positive psychology to motivate students and teachers and strengthening them as human being (Seligman, 1998, Seligman \& Csikszentmihalyi, 2000). We consider, in the style of Peterson (2006), a positive thinking that brings with it creativity and innovation, intellectual curiosity and social intelligence, transcendence as an appreciation of beauty and excellence in all areas of life (Hervás, 2009). The positive formation that derives from positive psychology is an ingredient of prosperity (Seligman, Ernst, Gillham, Reivich, \& Linkins, 2009) and our purpose is to bring the elevation in terms of Haidt (2000) to the didactic, with the aim of allowing teachers to discover and increase their talents, cultivate sensitivity and artistic intuition using art as a trigger in the flexibilization of creative thinking.

For this, an interdisciplinary workshop was created (thought and word, mind and body, music, visual arts) where the teachers, through practical and experiential activities, stimulate their imagination, recognize their talents in creative and innovative thinking and develop resources. Subsequently these resources, lead to their teaching practice, through the design of challenging learning experiences that stimulate the students to solve, creatively, tasks and projects.

To carry out the objective, we met eight professors from different areas (law, international relations, political science, languages, architecture, art, cultural advancement) convinced that creativity improves the performance of the teacher who rethinks his/her activities to allow the students learn to learn more dynamically. It sought to improve the performance of students who appreciated the approach to the subjects through didactic methods that the teachers had modified according to the passions observed outside the classroom. Activities were designed for the stimulation of creativity through the senses linking the content of the course to the discovery or affirmation of the talent of each student. It is taking into account the development of the artistic dimension so that the teachers discover within their area of specialty, their talents to create new ways of teaching the student to solve tasks and projects through the design of challenging experiences.

\section{EDUCATIONAL INNOVATION FROM THE TEACHING ACTIVITY}

With the purpose of contributing to the knowledge, we proposed a model to improve the teaching-learning process. In a context, that Carbonell Sebarroja (2015) recognizes as a concern about educational improvement, pointing that we speak about pedagogies on the 21 st century and not about the pedagogies. That is, the need to propose noninstitutional pedagogies that arise outside the school, that are critical and free of impositions, that bring the subjects that teach, closer to those that learn. You have to learn to innovate, says Pérez Tornero (2016), remembering that who is still the protagonist of teaching is the teacher, who was previously threaten by technology that now is his ally in the construction of learning paths.

Inés Aguerrondo (1999) points out that current educational systems, born as a result of industrialization, are organized on the basis of the definitions of science (knowledge), learning and content in force at the time they were generated. This process assumes that the student learns together with the teacher, empowering the student more by increasing their commitment in the learning process. The generational difference between students and teachers has become more evident in recent years due to the rapid technological evolution that has changed the way we live. We must worry about teacher training (Díaz \& Verduzco, 2011). as an emotional response towards the other (Marina \& y Marina, 2013).

Perhaps trying to measure the development of teaching activity through induced change requires several semesters of follow-up. Groups change and it may happen that the response of a team varies only because the members of a classroom in one semester are better than those who benefited in the previous semester, so it is proposed to work with new stimuli for the students of the last generation that begin with a change in the activities proposed by the teacher as well as has been experimented since the last century (Badina, 1971) and according to new characteristics of the approach to education (Acosta \& Centeno, 2011). According to Casal (1999), the student becomes a learning agent, becomes participatory, seeks communication, controls and defines their process and acquires confidence in their optional abilities. For this, he needs his guide, his coach, to be predisposed to approach his world.

Our task is to facilitate the learning process according to the needs and possibilities of the student. There is a lot of talent to exploit and sometimes goes unnoticed behind a low grade. That is why our purpose is, according to Barrio (2013), to form people, to reconcile Pedagogy with Philosophy to ensure human growth through educational 
innovation ingredients resulting from a synergistic sum between creating something new, the process in the one that is applied and the contribution of an improvement as a result of the process, and all this with a dependence on the context in which the supposed innovation is developed and applied (García-Peñalvo, 2015, p.6). Reviewing the contributions of Boyer (1990) who evokes the teacher's review of what to do differentiating the researcher's activity from the quality of teaching, emphasizes the fact that the academic must dedicate himself to the student to learn, this is his primary task, of course that if we can associate research and teaching we have a more qualified experience for the student body. In this regard, Morales (2010) invites to combine research and teaching by publishing about innovation, a way of researching about teaching. Bona García (2016), insists on the need to motivate, stimulate students' creativity, stoke their curiosity.

\section{OBJECTIVES}

Through the enrichment obtained during the sensory immersion, the objective of the research project is to implement learning activities through the imagination and measure the impact, in the student, of the use of creative activities. The hypothesis considers that teacher training through art and positive psychology favors the implementation of strategies that develop creative thinking in the delivery of classes and achieve a better appreciation by the students.

Specific objectives are to design a learning model based on innovation competencies; design a measurement plan to obtain the impact on learning and determine if the results of the measurement exercise a change in the student in the semester following the workshop taken by the teacher. The project aims to make teachers discover their talents and cultivate sensitivity and artistic intuition using art as a trigger in the flexibilization of creative thinking, to transform the teacher and enhance their talents. Students are expected to learn in a more dynamic way. Upload their grades and attend classes with more enthusiasm motivated by a more reflective, tolerant, analytical teacher, who goes beyond the reproduction of knowledge or information, with an innovative spirit, flexible, who knows how to work as a team, knows how to communicate and has knowledge technological (Tejada, 2002). The improvement is due to the different effort on the part of the teacher. It will be learning with emotions.

By generating a model of training in educational innovation in teachers that allows them to encourage innovation in students. Make Innovation a mental state, a lifestyle in teachers, transform them to be able to transform, and thus ensure our viability and permanence in the face of the challenges of the present and the future, creating a culture of innovation. This proposal arises from the concern to train inspiring and innovative teachers, leaders in their area of study, with experience in the practice of their profession, with the use of technology. They can be able to improve the competitiveness of students in their professional field by enhancing their own skills of the current generation, to develop the required competences that allow them to become the leaders that face the challenges and opportunities of the 21 st century. This is how this project arises, through the development of creativity and an open attitude that considers flexibility in how, when and where to generate learning and integrates challenging and interactive experiences in their teaching practice that can facilitate learning through innovation and creativity.

Among the advantages of the model, we emphasize that a process of training in educational innovation is generated in teachers that allows them to encourage innovation in students. Both teachers and students are enriched in the process. In addition, a culture of innovation is fostered and students are encouraged to build innovative and creative thinking that emerges from the teacher and manifests in a new learning environment. Among the disadvantages we find that it is a slow process of change. Several hours of training are needed and sometimes teachers do not have as much time available. There is a fear of criticism and there have been difficulties in measuring the impact on teachers and students.

\section{METHODOLOGY}

The methodology used for this project is based on a mixed research with population or sample concentrated in the students and teachers of the Tecnologico de Monterrey, Monterrey Campus, using data collection results of surveys. The project "Enseña con Pasión Aprende con Imaginación" turned out to be one of the winners of the NOVUS 2016 Experimentation in Educational Innovation contest. It deals with the topics of learning environments and teachinglearning strategies through the search for innovative spaces for learning and multidisciplinarity combined with adaptive learning in the environment of technologies for education. It is for the teachers who transversally teach courses at the academic levels of professionals with the aim of indirectly impacting students. The teachers who participated in this project are Carmelo Cattafi, Elena Jiménez Martín, Gabriel Gerardo Farah Piñón, Luzella 
Rodríguez López, Marcela Sada González, María Guadalupe Torres Garza, Nayra Mendoza Enríquez, Virginia Margarita Rosales Saldaña, all from Tecnológico de Monterrey, Monterrey Campus. The activities were applied in the courses Verbal expression in the professional field; Public International Law; Political Science Seminar; Readings and Videos; Public Speaking and Academic Writing; English Remedial IV; Introduction to the International Relations Career; Design of products and systems II and Introduction to Law Degree. In the results that are presented, only the courses that were taught by the same professor in two consecutive semesters and with a number of students greater than 12 per group are taken into account. For this reason, we presented data concerning 4 courses for a total of 260 students.

To measure the impact of the implementation of new activities, coupled with a feedback survey provided in the classroom; the Student Opinion Survey (ECOA) that students answer at the end of each semester was used. Of all the questions, the following were emphasized:

1) Regarding its role as a learning guide, it inspired me and showed commitment to my learning, development and integral growth.

2) Would you recommend a friend to take classes with this teacher?

3) Do you consider the teacher as one of the best teachers you have ever had?

The first two questions provide a response between 1 and 10 where 1 is the minimum value and 10 is the maximum value. For the third question the answer can be "yes" or "no". This work begins with the exploration of the theme of innovation in educational methodology in the teaching-learning process based on the teacher's competencies. This is the implementation of a project aimed at training teachers in order to design activities that allow students to approach the courses with the perception of transmitting passion and intellectual curiosity. We proceed with the design of the workshop, an entrance survey for teachers who attend the workshop. The teachers design an activity that they will apply in their classroom and document it. At the end of the semester teachers are interviewed who will share their experiences. One of the workshops proposed so that in a week the teachers had an immersion in this model, was contemplated sessions of music, dance, transmit with hands (sculpture), acting, awakening of the imagination (poetry), flexible thinking, storytelling, design of learning experiences.

\section{PROBLEMS ADDRESSED BY THE EDUCATIONAL INNOVATION PROJECT}

The contribution of this project is aimed at the teacher to internalize his innovative and creative work, and see himself as a transformative leader in his teaching practice, establishing new teaching-learning spaces. The teacher's work has been based on traditional teaching methods that consist of preparing a topic, standing in front of a group and teaching "chair", that is, transmitting knowledge verbally and in writing, waiting for the student to assimilate them and make them his own, to apply them in real world situations. The new educational models propose a change and suggest more actives teaching-learning processes, where the students participate in challenging learning activities that include the development of creativity, motivate them to learn, stimulate their intellectual capacities, the use of their multiple intelligences, and they are linked to the real world of their profession.

The activities are based on disruptive processes that allow the development and strengthening of creative skills and attitudes, to design strategies and innovative academic elements that can be incorporated into the teaching work. Through workshops aimed at discovering oneself and improving innovation and creativity skills, the aim is to improve the performance of the teacher and allow the student to learn more dynamically. It seeks to improve the performance of students who will appreciate more the approach to the subjects through didactic methods that the teacher modifies according to the passions that he has outside the classroom.

\section{IMPLEMENTED ACTIVITIES}

The project "Enseña con Pasión Aprende con Imagination", connected with the Educational Model Tec 21 (model of educational innovation implemented in the Tecnológico de Monterrey), aims for the teacher to achieve a personal change through self-knowledge, to strengthen their creative thinking and impact in his academic work. In this paragraph, we emphasize the activities implemented in the course of Public International Law. The activities implemented in the semester August-December 2016 and January-May 2017, stimulated learning in different ways according to the subject taught. For example, through art and poetry metaphors were used so that the student had a different approach to the discipline and managed to approach the most important concepts in a more encouraging way. 
Students managed to relate concepts with figures linked to their imagination and are invited, for example, to use an artistic technique to express their interpretation of the refugee issue. In the activity "learn through poetry", students had to interpret a poem in the light of a content of the curriculum of the subject, linking love with the negotiation of international treaties or a poem as "Waiting for the Barbarians" by Konstantino Kavafis to explain the Cold War. At the end of the activity it was much easier for students to understand international relations by analyzing them from different facets. Students demonstrated having assimilated concepts that sometimes are complicated and, most importantly, they did so enjoying their talent implementing activities using songs, movies, paintings, theater and of course, poetry. Also strengthening the competence of teamwork, the integration process, innovative thinking.

Among the activities implemented can also be mentioned the stimulation of creative writing through music and body movement. The lounge music was used and breathing exercises were applied to the music before writing a short story in English. The theme was varied and the students seized the story to the point that the omission of beginning, middle and end could have been valid. Students improve their performance and appreciate the relaxation technique that inspires them to be creative by developing communicative competence written with creativity and imagination. The construction of his own story through the technique of Storytelling valued another experience.

\section{OUTCOMES}

As mentioned above, the measurement instrument relies on the analysis of a periodic survey that is provided to students at the end of each semester. Below in Table 1, we present the results obtained after the implementation of the activities comparing two consecutive semesters with classes taught by the same teacher.

Table 1. Comparison of student survey results.

\begin{tabular}{l|l|l|l|c}
\hline \multicolumn{1}{c}{ Course/question } & Q1 & Q2 & Q3 \\
\multirow{2}{*}{ Public International Law } & May 2017 & 9.8 & 9.8 & $85 \%(20$ students $)$ \\
\hline \multirow{2}{*}{ Design of products and systems II } & Dec. 2016 & 8.85 & 7.85 & $55 \%(20$ students) \\
\hline \multirow{2}{*}{ Verbal expression in the professional field } & May 2017 & 9.29 & 8.8 & $50 \%(19$ students) \\
\cline { 2 - 5 } & Dec. 2016 & 7.11 & 6.33 & $11 \%(13$ students) \\
\hline \multirow{2}{*}{ Public Speaking and Academic Writing } & May 2017 & 9.70 & 9.68 & $73 \%(77$ students) \\
\cline { 2 - 5 } & Dec. 2016 & 9.21 & 9.46 & $72 \%(63$ students) \\
\cline { 2 - 5 } & May 2017 & 9.43 & 9.50 & $82 \%(28$ students) \\
\hline
\end{tabular}

Source: Own elaboration

In the table to each course represented in the first column, 3 questions are associated. The Q1 is the average of the score between 1 and 10 to the question "Regarding its role as a learning guide (it inspired me and showed commitment to my learning, development and integral growth)". The Q2 is the average of the score between 1 and 10 to the question "Would you recommend a friend to take classes with this teacher?". Q3 is the percentage that answered yes to the question: "Do you consider the teacher as one of the best teachers you have had?"

The semester January-May 2017 is compared with the semester August-December 2016. Periods where the activity began to be implemented. In the semester January-May 2017, the improved activities were implemented to have a better impact in the teaching-learning process. The satisfactory results confirm the hypothesis that teacher training through art and positive psychology favors the implementation of strategies that develop creative thinking in the delivery of classes and achieve a better appreciation by the students in Figure 1as given below: 
Figure 1. Satisfactory Results

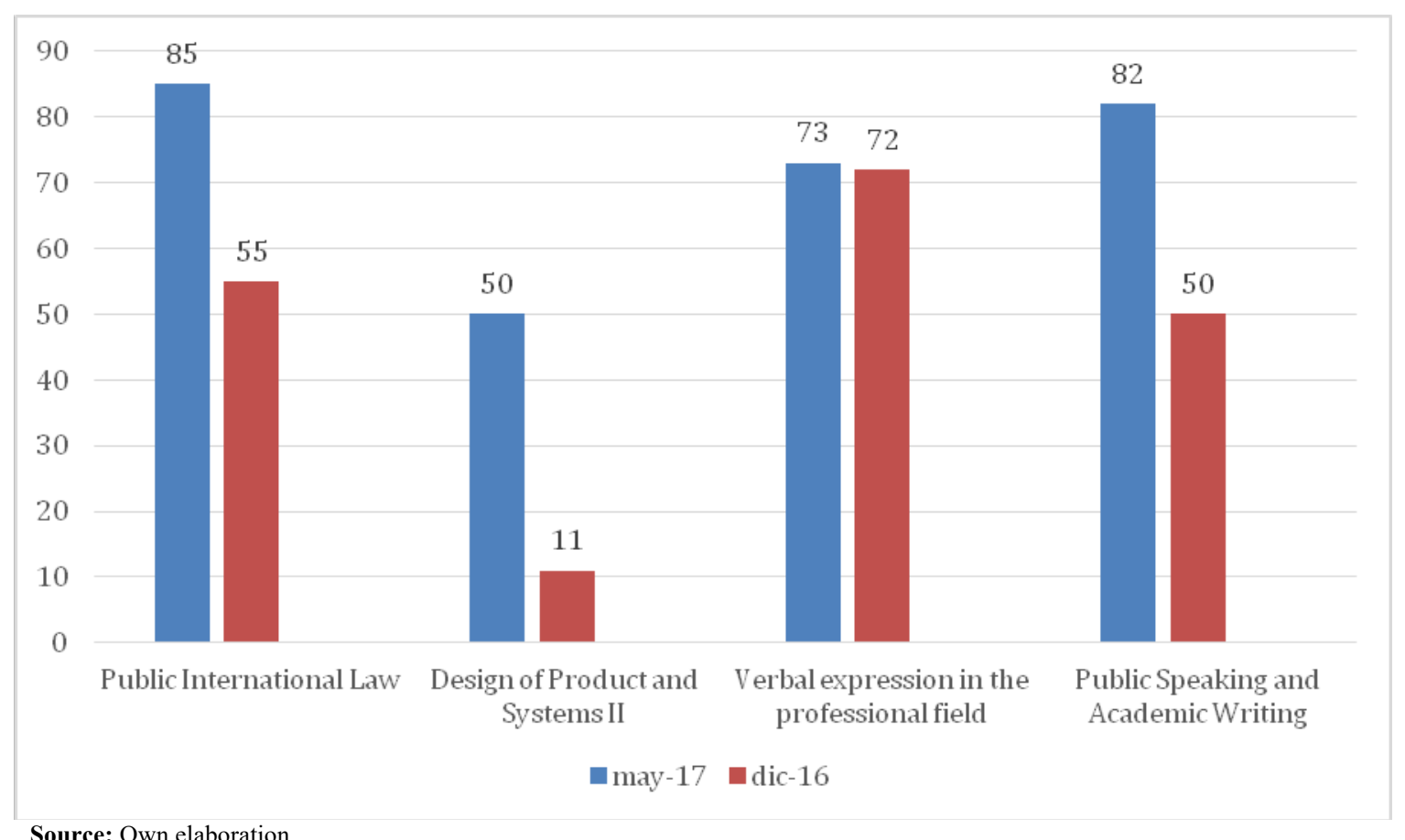

Source: Own elaboration

Through the graph we can see how the implementation of new activities linked to creativity workshops has allowed teachers to have a better impact on the opinion of students. For example, with a total of 40 students, in the class of public international law, $55 \%$ went to $85 \%$ to consider the teacher as one of the best teachers they have had. With a total of 32 students, in the class of Design of products and systems II, from $11 \%$ it was passed to $50 \%$ of students who consider the teacher as one of the best teachers they have had. With a total of 140 students, in the verbal expression class in the professional field, $72 \%$ went to $73 \%$ to consider the teacher as one of the best teachers they have had. Finally, with a total of 50 students, in the Public Speaking and Academic Writing class of $50 \%, 82 \%$ went on to consider the teacher as one of the best teachers they have ever had. In the exercise a very significant increase is noticed.

\section{CONCLUSIONS}

Can students be learned in a more dynamic way? Can you improve their grades and attend classes with more enthusiasm motivated by a teacher who uses emotions to bring the student closer to the subject? According to our results, students manage to relate concepts with figures linked to their imagination, improve their performance and appreciate the educational methodology. The feedback provided by the students about the innovative experience they witnessed has been positive and constant since the first implementation of the methodology in the semester JanuaryMay 2016 with professional students of the Tecnológico de Monterrey, Campus Monterrey. For this work, the results of the official surveys that the students answer at the end of the semester courses were taken into account. The data related to two periods were compared: August-December 2016 and January-May 2017. This reflects one of the advantages of competency-based education, that is, stimulating knowledge and fostering a passion for self-learning.

Through the development of creativity and an open attitude that considers flexibility in how, when and where to generate learning, challenging and interactive experiences are integrated into the teaching practice. The proposal is the result of the implementation of a project that arises from the concern to train teachers capable of improving the competitiveness of students in their professional field by enhancing the skills of the current generation.

According to De Bono (1994), creativity is not an inherent ability or skill, the result of natural talent, but a skill that everybody can activate and develop. On the other hand, according to Muñoz (1994), originality is not something fully developed, it is part of creative thinking but takes into account quantity of creative products and how many creative 
products we can develop. The identified factors that intervene in creative development include: tolerance, freedom, flexibility, search for novelty, divergent thinking and risk capacity. Among them there are negative factors: fear of criticism, fear of being wrong, excessive perfectionism, accepting stereotypes and being different (Balart and Césped, 1998, p.16).

Our activities seek to foster a creative environment that is free, where flexible thinking encourages self-evaluation and learning based on motivation. It is a concept oriented to the teacher to internalize his innovative and creative work, and see himself as a transforming leader in his teaching practice, establishing new teaching-learning spaces (Christensen, 1991) form a learning community and be an ally of students and with them establish a learning contract.

From the point of view of some teachers, the limitation of the project can be presented in the resistance to change. Several hours of training are needed and sometimes teachers do not have as much time available. There is a fear of criticism because certain activities are far from the master classes, however, it has been noted that students learn more through an activity that links a content with a poem or a song. On the other hand, there were difficulties in measuring the impact on teachers and students because the teacher's assessment tool has been different in recent years and it may be difficult to find a cause-effect relationship between performance of the student and the implementation of the activity because the groups are different in each semester. This project helps the teacher to generate different innovative and creative learning environments to stimulate students.

The artistic awareness, creativity and the teacher transforms in this work was apparent. Students' motivation is encouraged by seeing that the teacher has the capacity for change and becomes the protagonist of innovation in the process of adapting to their needs and demands. Positive change in people goes beyond the classroom. By sharing the implemented activities, teachers impact their colleagues and students can apply different ways of learning in other classes. Due to the change that occurs in the teacher, the process can be replicated in other courses and disciplines because directly related to the human being. In the book of 30 interviews with education experts of the Blog of Education and ICT (Tonucci, 2016), many ideas for teaching to young people appear today is not evident the need to make students work in creation of their learning environments. Teach with passion and learn with imagination is nourished just by the contribution of students stimulated by the products of educational innovation that come from the teaching work.

\section{AUTHOR BIOGRAPHY}

Carmelo Cattafi is an educator and researcher at the Tecnológico de Monterrey, México. ccattafi@itesm.mx

\section{REFERENCES}

Acosta, F., y Centeno, C. G. P. (2011). Re-bordering comparative education in Latin America: Between global limits and local characteristics. International Review of Education / Internationale Zeitschrift Für Erziehungswissenschaft / Revue Internationale De L'education, 57(3/4), 477-496.

Aguerrondo, I. (1999). El nuevo paradigma de la educación para el siglo. Organización de Estados Iberoamericanos para la Educación, la Ciencia y la Cultura. Recuperado de: http://www.oei.es/historico/administracion/aguerrondo.htm.

Badina, O. (1971). La educación del educador. Revista Mexicana De Sociología, 33(1), 51-59. http://doi.org/10.2307/3539523 https://www.jstor.org/stable/3539523

Balart Carmona, C., \& y Césped Benítez, I. (1998). Electra y Orestes, la cosmovisión linaje, familia y hogar. Revista signos, 31(43-44), 17-35.

Barrio, J. M. (2013) La innovación educativa pendiente: Formar personas. Barcelona, Erasmus Ediciones

Bona García, C. (2016). La nueva educación: Los retos y desafios de un maestro de hoy (13a ed.). Barcelona: Plaza Janés.

Boyer, E.L. (1990). Scholarship reconsidered: Priorities of the Professoriate. Princeton, New Jersey: Princeton University Press, The Carnegie Foundation for the Advancement of Teaching.

Carbonell Sebarroja, J. (2015). Pedagogías del siglo XXI: Alternativas para la innovación educativa. Barcelona: Ediciones Octaedro.

Casal, I. I. (1999). La creatividad en el proceso de enseñanza-aprendizaje de ELE: caracterización y aplicaciones. In Actas del X Congreso Internacional de Asele.

Christensen, C. R. (1991). Education for judgment: The artistry of discussion leadership. Harvard Business School Press, Boston, MA 02163

De Bono, E. (1994). Parallel thinking. London: Viking.

Díaz Rivera, J., y Verduzco, E. (2011). ¿Por qué preocuparse por la formación docente? Eutopia, (16).

García-Peñalvo, F. J. (2015). Mapa de tendencias en innovación educativa. Teoria De La Educacion, 16(4), 6-23. 
Haidt, J. (2000). The Positive emotion of elevation. Prevention \& Treatment, 3(1)

Hervás, G. (2009). Psicología positiva: una introducción. Revista interuniversitaria de formación del profesorado, 23(3).

Marina, J. A., y Marina, E. (2013). El aprendizaje de la creatividad. Ariel.

Morales, P. (2010). Investigación e innovación educativa. REICE: Revista Electrónica Iberoamericana Sobre Calidad, Eficacia y Cambio En Educación, 8(2), 47-73.

Muñoz, F. I. (1994). La formación del profesorado.

Pérez Tornero, J. M. (2016). Ideas para aprender a aprender: Manual de innovación educativa y Tecnología Editorial UOC.

Peterson, C. (2006). A primer in positive psychology. Oxford University Press.

Seligman, M.E.P. (1998). Learned optimism: How to change your mind and your life. (2a. ed.). New York, NY: Pocket Books.

Seligman, M. E., Ernst, R. M., Gillham, J., Reivich, K., \& Linkins, M. (2009). Positive education: Positive psychology and classroom interventions. Oxford review of education, 35(3), 293-311.

Seligman, M. E. P. \& y Csikszentmihalyi, M. (2000). Positive psychology: An introduction. American Psychologist, 55, 5-14

Tejada Fernández, J. (2002). La formación de formadores. Apuntes para una propuesta de plan de formación. Educar, (30), 91118.

Tonucci, F. (2016). Hablemos de educación: Reflexiones educativas para cambiar el mundo (Primeraón ed.). España: Tiching blog. 